\title{
Flue gas treatment by power-to-gas integration for methane and ammonia synthesis - Energy and environmental analysis
}

\author{
Beatrice Castellani $^{\mathrm{a}, *}$, Sara Rinaldi ${ }^{\mathrm{a}}$, Elena Morini ${ }^{\mathrm{a}}$, Benedetto Nastasi ${ }^{\mathrm{b}}$, Federico Rossi $^{\mathrm{c}}$ \\ a Department of Engineering, Interuniversity Research Centre on Pollution and Environment "Mauro Felli"(CIRIAF), University of Perugia, Via G. Duranti 67, 06125 \\ Perugia, Italy \\ ${ }^{\mathrm{b}}$ Department of Architectural Engineering and Technology (AE+T), TU Delft University of Technology, Julianalaan 134, 2628 BL Delft, The Netherlands \\ ${ }^{\mathrm{c}}$ Department of Engineering, Interuniversity Research Centre on Pollution and Environment "Mauro Felli"(CIRIAF), University of Perugia, Scientific Pole of Terni, Pentima \\ Bassa, 05100 Terni, Italy
}

\section{A R T I C L E I N F O}

\section{Keywords:}

Flue gas

Power to gas

$\mathrm{CO}_{2}$ methanation

Ammonia synthesis

Carbon and energy footprint

LCA life cycle assessment

\begin{abstract}
A B S T R A C T
The present paper aims at assessing the carbon and energy footprint of an innovative process for carbon dioxide recycling, with flue gas as feedstock of nitrogen and carbon dioxide. Nitrogen is converted into ammonia through the Haber-Bosch process and carbon dioxide into methane via Sabatier reaction using hydrogen produced by renewable electricity excess. Carbon and energy footprint analysis of the process was assessed based on experimental data related to hydrogen production by electrolysis, methane synthesis via Sabatier reaction, energy consumption and energy output of the process units for flue gas separation, carbon dioxide methanation and ammonia synthesis. A Life Cycle Assessment method is applied, based on the experimental and computational data, both in case of renewable electricity excess and electricity from the grid. Results show that in case of renewable electricity excess, for a functional unit of $1 \mathrm{~kg}$ of treated flue gas, the specific carbon footprint is $0.7819 \mathrm{~kg}_{\mathrm{CO} 2 \mathrm{eq}}$ and energy footprint is $50.73 \mathrm{MJ}$, which correspond to $4.012 \mathrm{~kg}$ and $260.3 \mathrm{MJ}$ per $1 \mathrm{~kg}$ of produced hydrogen. In case of electricity from the grid, the specific carbon footprint is $1.550 \mathrm{~kg}_{\mathrm{CO} 2 \mathrm{eq}}$ and energy footprint is $59.12 \mathrm{MJ}$ per flue gas mass unit. If the carbon footprint is positive, the process indirectly leads to avoided emissions, ranging from 0.673 to $0.844 \mathrm{~kg}_{\mathrm{CO} 2 \mathrm{eq}} \mathrm{kg}_{\text {fluegas }}^{-1}$, thus proving the sustainability of the proposed pathway.
\end{abstract}

\section{Introduction}

Moving towards the implementation of the Circular Economy plan at European level drew attention to the waste and by-products of a process [1]. Resource efficiency, i.e. reducing the raw material dedicated to obtain a certain amount of product, should be coupled with the utilization of the other results of the process for increasing the yield of the process itself or to provide raw material to others. Among such options, flue gas is the by-product of fuel combustion [1]. Flue gas is composed by Greenhouse Gases (GHG), mainly carbon dioxide $\left(\mathrm{CO}_{2}\right)$ entailing negative effects on the environment. In order to comply with law in force the industry sector has to be equipped with $\mathrm{CO}_{2}$ removal technologies [2]. Residual $\mathrm{CO}_{2}$ may be used to produce gaseous or liquid fuels via a large number of pathways based on the transformation of renewable energy [3]. Power-to-gas (PtG) process converts electricity into hydrogen $\left(\mathrm{H}_{2}\right)$ through water electrolysis and then methane $\left(\mathrm{CH}_{4}\right)$ is produced from $\mathrm{CO}_{2}$ and $\mathrm{H}_{2}$ via Sabatier reaction. PtG technology is studied with energy purposes to allow a better integration of the fluctuating renewable energy in the electric grid.

There are several pilot and demonstration plants, mainly in Europe, both for $\mathrm{H}_{2}$ and synthetic $\mathrm{CH}_{4}$ production, which have proven the viability of the technology [3]. PtG system variations and configurations devoted to the production of $\mathrm{H}_{2}$ and $\mathrm{CH}_{4}$ have been extensively studied from a technical and environmental point of view, also in combination with anaerobic digestion. Collet et al. [4] compared two biogas upgrading scenarios (with amines and membrane technologies), and three scenarios with the use of PtG technologies to produce bioCH with a fossil reference one of $\mathrm{CH}_{4}$ production from natural gas. They found that PtG technologies are competitive economically with upgrading scenarios for an average electricity price equal to $38 € \mathrm{MW} \mathrm{h}^{-1}$ for direct methanation and separation by membranes. In case of intermittent operation, competitive prices of electricity for methanation can be higher, depending on the operation time. As far as environmental aspects are concerned, results showed that impacts of PtG are higher

\footnotetext{
* Corresponding author.

E-mail addresses: beatrice.castellani@unipg.it (B. Castellani), rinaldi@crbnet.it (S. Rinaldi), morini@crbnet.it (E. Morini), benedetto.nastasi@outlook.com (B. Nastasi), federico.rossi@unipg.it (F. Rossi).
} 


$\begin{array}{ll}\text { Nomenclature } \\ \text { Acronyms } \\ \text { CED } \quad \text { Cumulative Energy Demand } \\ \text { CF } & \text { Carbon Footprint } \\ \text { COP } & \text { Coefficient Of Performance } \\ \text { EF } & \text { Energy Footprint } \\ \text { GHG } & \text { Greenhouse Gases } \\ \text { GWP } & \text { Global Warming Potential } \\ \text { HHV } & \text { Higher Heating Value } \\ \text { IPCC } & \text { International Panel on Climate Change } \\ \text { LCA } & \text { Life Cycle Assessment } \\ \text { PEM } & \text { Proton Exchange Membrane } \\ \text { PtG } & \text { Power to Gas } \\ \text { PV } & \text { Photovoltaics }\end{array}$

Chemical symbols

$\begin{array}{ll}\mathrm{CH}_{4} & \text { Methane } \\ \mathrm{CO}_{2} & \text { Carbon Dioxide } \\ \mathrm{H}_{2} & \text { Hydrogen } \\ \mathrm{H}_{2} \mathrm{O} & \text { Water } \\ \mathrm{HCl} & \text { Hydrogen Chloride } \\ \mathrm{KOH} & \text { Potassium Hydroxide } \\ \mathrm{N}_{2} & \text { Nitrogen } \\ \mathrm{NH}_{3} & \text { Ammonia } \\ \mathrm{Ni} & \text { Nickel } \\ \mathrm{NiO}_{2} & \text { Nickel Oxide } \\ \mathrm{NOx} & \text { Nitrogen Oxides } \\ \mathrm{O}_{2} & \text { Oxygen } \\ \mathrm{PtG}_{\mathrm{SG}} & \text { Power To Gas } \\ \mathrm{SO} & \text { Sulfur Dioxide } \\ \mathrm{Zr} & \text { Zirconium }\end{array}$

\section{$\mathrm{Al}_{2} \mathrm{O}_{3} \quad$ Aluminum Oxide}

than biogas upgrading for continuous operation, while intermittent operation can severely lower the environmental impact for non-direct methanation scenarios if the consumed electricity is mainly renewable. In [5] it was assessed that PtG systems are competitive economically with conventional gas production systems when other services, such as heat and oxygen supply are provided and bring environmental benefits only when supplied with renewable sources. Castellani et al. [6] studied experimentally the integration of PtG technology with hydrate-based biogas upgrading, concluding that there are benefits in terms of net energy stored, as gaseous $\mathrm{CH}_{4}$, passing from raw biogas utilization to the integration of biogas upgrading with $\mathrm{CO}_{2}$ methanation. The energy content improvement is $41.2 \%$. Nevertheless, the addition of hydrogen electrolysis within the energy system boundaries brings significant energy losses. Indeed, the energy benefit is reduced to $0.1 \%$.

Zhang et al. [7] compared the environmental performance of PtG with conventional $\mathrm{H}_{2}$ and natural gas production and utilization. They found that the best option in terms of GHG emission reduction is renewable electricity supply coupled with biogenic $\mathrm{CO}_{2}$ sources.

A new research line related to the so-called synthetic fuel started with $\mathrm{CO}_{2}$ sequestration from flue gas and its reaction with $\mathrm{H}_{2}$ to produce methanol $[8,9]$ by combining the GHG emission reduction with the use of renewable electricity excess due to the increase of the intermittent renewable energy supply or even combined with other waste heat such as in [10]. This synergy is extended to inter-sectorial systems [11] and multiple fuels production [12] for feeding power plants or producing further raw material in industrial processes.

In this perspective, $\mathrm{H}_{2}$ from renewable energy can be used to produce chemicals, such as ammonia $\left(\mathrm{NH}_{3}\right)$, in addition to $\mathrm{CH}_{4} \cdot \mathrm{NH}_{3}$ is produced conventionally via the Haber-Bosch process, which combines $\mathrm{H}_{2}$ from steam reforming of natural gas and nitrogen $\left(\mathrm{N}_{2}\right)$ from cryogenic air separation. In the literature, several studies show Life Cycle Assessment (LCA) of various $\mathrm{NH}_{3}$ production paths: biomass gasification [13], municipal waste, hydropower and nuclear energy for $\mathrm{H}_{2}$ production [14].

The present paper proposes flue gas as a source of reactants, both for synthetic $\mathrm{CH}_{4}$ and $\mathrm{NH}_{3}$ production. Flue gas is a gaseous industrial waste, composed mainly by $\mathrm{N}_{2}$ and $\mathrm{CO}_{2} . \mathrm{N}_{2}$ and $\mathrm{CO}_{2}$ constitute feedstock for $\mathrm{NH}_{3}$ and $\mathrm{CH}_{4}$ production, respectively, if combined with $\mathrm{H}_{2}$. Considering the state of art, this is the first study in the literature on the flue gas treatment process for the $\mathrm{NH}_{3}$ production via Haber-Bosch synthesis and the $\mathrm{CH}_{4}$ production via Sabatier reaction in combination with electrolysis for $\mathrm{H}_{2}$ production. The proposed integrated process addresses a double challenge: (i) recycling of an industrial waste, such as flue gas, and its conversion into a $\mathrm{CO}_{2} / \mathrm{N}_{2}$ source for high-value products, $\mathrm{CH}_{4}$ and $\mathrm{NH}_{3}$ and (ii) utilization of renewable energy for $\mathrm{H}_{2}$ production as an energy storage option.

The Energy Footprint (EF) and the Carbon Footprint (CF) will be assessed with the support of experimental data as analyzed by some of the authors in a previous study [15], in which an environmental assessment is performed to evaluate the production of methane from hydrate-based biogas upgrading coupled with PtG technology. The CF and $\mathrm{EF}$ are evaluated to understand the impact of the proposed solution, in terms of GHG emissions and primary energy consumption. The results are presented and compared with traditional production processes.

\section{Methods}

The treatment process of flue gas, consisting of four main phases, is described in the following section. Deriving from the deep analysis of the process and experimental tests, the energy balance and environmental assessment are computed.

\subsection{Process description}

The proposed process treats flue gas, the final gaseous product of combustion, to produce $\mathrm{CH}_{4}$ and $\mathrm{NH}_{3}$ through renewable energy excess exploitation. For their composition, flue gases from fossil fuel-fired combustion facilities are major contributors to atmospheric pollution [16]. The composition of flue gases depends on the fuel source, the power plant and treatments; however, they generally consist of $\mathrm{CO}_{2}, \mathrm{~N}_{2}$, oxygen $\left(\mathrm{O}_{2}\right)$ and water $\left(\mathrm{H}_{2} \mathrm{O}\right)$, sulfur dioxide $\left(\mathrm{SO}_{2}\right)$, nitrogen oxides $\left(\mathrm{NO}_{\mathrm{x}}\right)$ and hydrogen chloride $(\mathrm{HCl})$. For the purposes of the investigation, a flue gas composed by $\mathrm{CO}_{2}$ and $\mathrm{N}_{2}$ is considered. Previous stages of purification are not taken into account.

$\mathrm{CO}_{2}$ and $\mathrm{N}_{2}$ from flue gas are separately combined with $\mathrm{H}_{2}$ in the Sabatier reaction to produce $\mathrm{CH}_{4}$ and in the Haber-Bosch process to produce $\mathrm{NH}_{3}$, respectively. The overall process is shown in Fig. 1 .

The separation of $\mathrm{CO}_{2}$ and $\mathrm{N}_{2}$ is carried out by silicone hollow fiber membrane technology. The $\mathrm{H}_{2}$ that is required to realize the Sabatier reaction and the Haber-Bosch process is provided by electrolysis of water [17] based on renewable energy excess use.

$\mathrm{CO}_{2}$ and $\mathrm{H}_{2}$ are combined by Sabatier reaction, with a stoichiometric ratio of $1: 4$ and produces $\mathrm{CH}_{4}$ and water exothermically as shown in Eq. (1):

$\mathrm{CO}_{2}+4 \mathrm{H}_{2} \leftrightarrows \mathrm{CH}_{4}+2 \mathrm{H}_{2} \mathrm{O}$ 


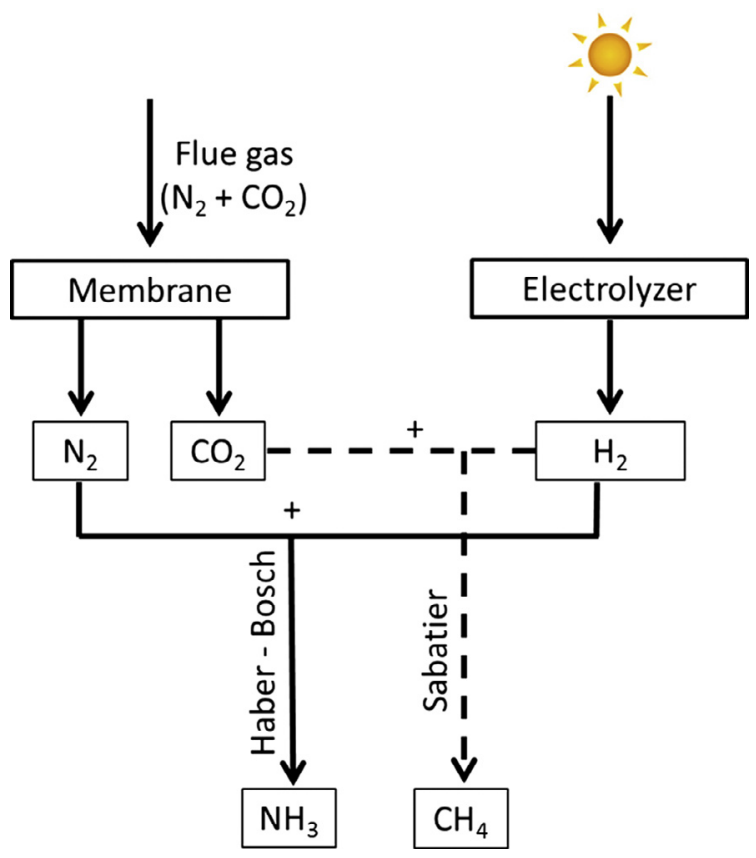

Fig. 1. Scheme of the combined processes to produce $\mathrm{NH}_{3}$ and $\mathrm{CH}_{4}$ from flue gas.

$\mathrm{N}_{2}$ is combined with $\mathrm{H}_{2}$ in accordance with the Haber-Bosch process, with a stoichiometric ratio of 1:3 and in presence of a catalyst based on magnetite. The chemical reaction for $\mathrm{NH}_{3}$ production is shown in Eq. (2):

$\mathrm{N}_{2}+3 \mathrm{H}_{2} \leftrightarrows 2 \mathrm{NH}_{3}$

Methane and ammonia are stored in the gaseous form.

In the following sub-sections, the considered processes are described.

\subsubsection{Carbon dioxide/Nitrogen separation}

Various technologies are used for post-combustion $\mathrm{CO}_{2}$ separation: absorption with solvents or solid sorbents, pressure and temperature swing adsorption with several solid sorbents, cryogenic separation, membranes and other several emerging technologies. Among these ones, clathrate hydrates are widely studied in the last few years [18]. In accordance with reviews in the literature, membranes will be significantly more efficient at separation than liquid absorption soon, which is currently considered the most promising method [19]. In addition, membranes have several advantages over conventional separation techniques, such as low environmental impact, favorable economics, ease of operation, and low maintenance [20]. Several typologies of membranes are available for $\mathrm{CO}_{2}$ separation purposes: polymeric and inorganic membranes, mixed matrix membranes, facilitated transport membranes and carbon membranes. A comprehensive list of membranes and their permeability to $\mathrm{CO}_{2}$ and $\mathrm{N}_{2}$ is available in [21]. According to [22], a polymeric gas separation membrane guarantees the separation of $\mathrm{CO}_{2}$ from other gases, a good permeation to the gas to have an intense gas flux during separation, as well as good thermal and mechanical properties. In the present paper, the selected membrane module is constituted by hollow fibers, which are small silicone micro-tubes with very thin walls (supplied PermSelect ${ }^{\circledR}$ ). Technical data are shown in Table 1.

Hollow-fiber membranes have a higher productivity in the processes of separation, since they provide high area-to-volume ratio, low resistance to gas flow and the ability to support high transmembrane pressure drops [23]. Since silicone is dense, the separation occurs because of the permeability difference between gases in the fibers. The permeability coefficient is a parameter defined as the transport flux of a gas (rate of gas permeation per unit area), per unit transmembrane driving force per unit membrane thickness [24]. The permeability coefficient, at $298 \mathrm{~K}$ and $0.1 \mathrm{MPa}$, for $\mathrm{N}_{2}$ is 280 barrer while for $\mathrm{CO}_{2}$ it is 3250 barrer [25]. The separation factor, calculated as the ratio between the two permeability coefficients is equal to 11.6 and this value in accordance with technical data by the supplier ensures an excellent separation. The $\mathrm{N}_{2} / \mathrm{CO}_{2}$ mixture enters the membrane module through the inlet port to the tube side and flows through the inside of the hollow fibers. $\mathrm{CO}_{2}$ has the highest permeability and so transfers across the hollow fiber walls leaving behind $\mathrm{N}_{2}$. The transferred gas is referred to as the permeate (in this case the permeate is $\mathrm{CO}_{2}$ ). Exiting the outlet of the tube side is the retentate, which constitutes a gas mixture with a higher concentration of $\mathrm{N}_{2}$.

According to both [26,27], the trade-off between permeability and selectivity limits the achievement of simultaneous high degree of $\mathrm{CO}_{2}$ separation and high $\mathrm{CO}_{2}$ purity with a one single-stage membrane. To reach $90 \% \mathrm{CO}_{2}$ separation and a $95 \mathrm{~mol} \% \mathrm{CO}_{2}$ purity, a two-stage membrane section with recirculation is considered, as shown in Fig. 2.

The separation section, shown in Fig. 2, uses a compressor at 0.4 MPa for the feed flue gas and a vacuum pump at 0.01 MPa. Energy calculations on this configuration are presented in [28] and energy consumption is equal to $878.4 \mathrm{~kJ}_{\mathrm{el}}$ per mass unit of separated $\mathrm{CO}_{2}$. In accordance with [28], this value is consistent with energy consumption of ammine-based process, which is the most used carbon capture technology.

\subsubsection{Hydrogen production}

Water is decomposed into $\mathrm{O}_{2}$ and $\mathrm{H}_{2}$ by an electric current being passed through the water. The electrolysis of one mole of water produces a mole of $\mathrm{H}_{2}$ gas and a half-mole of $\mathrm{O}_{2}$ gas in their normal diatomic forms. Two moles of water undergo the transformation in Eq. (3):

$2 \mathrm{H}_{2} \mathrm{O}+$ electrical energy $\rightarrow \mathrm{O}_{2}+2 \mathrm{H}_{2}$

Three water electrolysis technologies are widely investigated: alkaline electrolysis, Proton Exchange Membrane (PEM) electrolysis and solid oxide electrolysis. For large-scale applications, the most used water electrolysis technology is the alkaline process, while PEM technology is less mature than the alkaline one and is mostly used for small-scale applications [29]. Solid oxide electrolysis is the least developed process and it is not yet widely commercialized [30]. The electrolyzer used in the experimental tests is based on PEM technology and is supplied by Erre Due Srl (H03 series). Technical characteristics of the electrolyzer are shown in Table 2. The energy efficiency, defined as the Higher Heating Value (HHV) of $\mathrm{H}_{2}$ divided by the energy consumed by the electrolysis system per $\mathrm{kg}$ of $\mathrm{H}_{2}$, is equal to $57.4 \%$.

The electrolyzer was put in operation in 2005 and its power consumption is quite high with respect to other devices in the market. As a matter of fact, several studies in the literature show that power consumption can reach values of $15480 \mathrm{~kJ}$ per $\mathrm{Nm}^{3}$ of $\mathrm{H}_{2}$ for alkaline technology and $14760 \mathrm{~kJ} \mathrm{Nm}^{-3}$ for PEM technology [31]. A reduction of $10 \%$ on the alkaline electrolysis energy consumption was observed when compounds of three d-metals (ZnCoMo) were added to the standard potassium hydroxide (KOH) solution [32]. Commercial alkaline electrolyzer, supplied by Nel Hydrogen, has: (i) a declared power

Table 1

Membrane module characteristics and operating conditions.

\begin{tabular}{ll}
\hline Parameter & Value/typology \\
\hline Membrane material & PDMS (Silicone) \\
Membrane type & Dense Hollow Fiber \\
Fiber ID $(\mu \mathrm{m})$ & 190 \\
Fiber wall thickness $(\mu \mathrm{m})$ & 55 \\
Max continuous operating temperature $(\mathrm{K})$ & 333 \\
Max shell side pressure $(\mathrm{MPa})$ & 1.5 \\
Typical gas flow rate $\left(\mathrm{Nm}^{3} \mathrm{~h}^{-1}\right)$ & 3.9
\end{tabular}




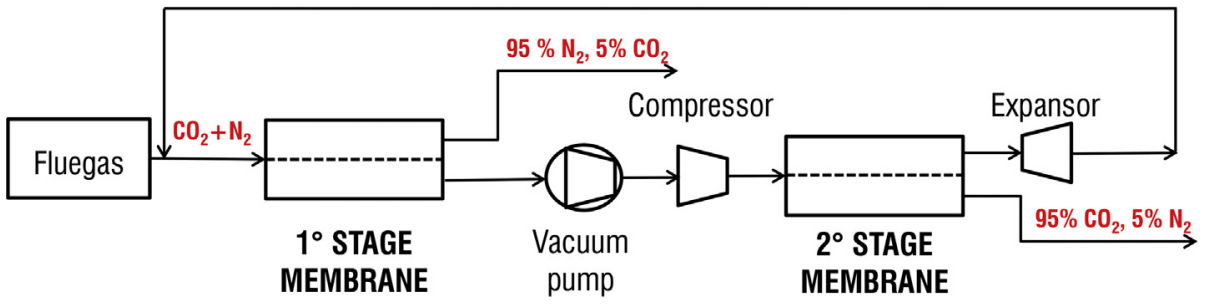

Fig. 2. Membrane separation section [27]
Table 2

Electrolyzer technical data.

\begin{tabular}{ll}
\hline Parameter & Value \\
\hline Operating pressure (MPa) & 0.25 \\
Flow rate $\left(\mathrm{Nm}^{3} \mathrm{~h}^{-1}\right)$ & 2.5 \\
Power consumption $(\mathrm{MJ} \mathrm{Nm}$ & -3 ) \\
\hline
\end{tabular}

consumption down to $13680 \mathrm{~kJ} \mathrm{Nm}^{-3}$ (in the range of $13680-15840 \mathrm{~kJ}$ $\mathrm{Nm}_{\mathrm{H} 2}^{-3}$ ) with a 78-90\% energy efficiency and (ii) a water consumption of $0.9 \mathrm{~L}$ per $\mathrm{Nm}^{3}$ of produced $\mathrm{H}_{2}$, with a water-to-hydrogen conversion efficiency of $89 \%$ [33].

\subsubsection{Methane production}

The Sabatier reaction, used for $\mathrm{CH}_{4}$ production from $\mathrm{CO}_{2}$, is exothermic $\left(\Delta \mathrm{H}^{\circ}=-165 \mathrm{~kJ} \mathrm{~mol}^{-1}\right)$ and occurs within the optimal temperature range $523-673 \mathrm{~K}$, in order to guarantee a higher $\mathrm{CO}_{2}$ conversion and, consequently a higher $\mathrm{CH}_{4}$ selectivity. Heat produced by the exothermic reaction is, thus, removed to maintain a relatively low process temperature (around $623 \mathrm{~K}$ ). Pressure is directly proportional to $\mathrm{H}_{2}$ conversion and its effect is improved at higher temperatures, where the equilibrium constant is low. The methanation of $\mathrm{CO}_{2}$ is thermodynamically convenient $\left(\Delta \mathrm{G}_{298 \mathrm{~K}}=113.5 \mathrm{~kJ} \mathrm{~mol}^{-1}\right)$. However, the reduction of the fully oxidized carbon to $\mathrm{CH}_{4}$ is an eight-electron process with important kinetic limitations. Therefore, a catalyst is used for reaching acceptable rates and selectivity. Nickel was the first catalyst used when Paul Sabatier discovered this process in 1897 and it is still commonly used due to its availability and relative low cost. A support with high surface area, usually oxides, has been applied extensively for the preparation of metal catalysts. The most widely used reactor design for methanation processes is the fixed bed reactor.

The $\mathrm{CO}_{2}$ methanation process was studied experimentally through the operation of a lab-size apparatus. The schematic diagram is shown in Fig. 3.

The apparatus is composed of an electrolyzer for $\mathrm{H}_{2}$ production from Photovoltaic (PV) system, a $\mathrm{CO}_{2}-\mathrm{H}_{2}$ mixing section, a heating section, a Sabatier reactor and a water separation section. $\mathrm{H}_{2}$ from the electrolyzer is mixed with $\mathrm{CO}_{2}$ from gas bottles in stoichiometric proportion. The gaseous mixture passes in the heating section, which is a horizontal tube (diameter of $25.4 \mathrm{~mm}$ and length of $300 \mathrm{~mm}$ ) equipped with three $700 \mathrm{~W}$ mineral insulated band heaters, provided by Watlow. The heating section is connected to the Sabatier reactor through a gate valve (supplied by Swagelok, model SS-6nbs $10 \mathrm{~mm}-\mathrm{G}$ ). The Sabatier reactor is a cylindrical AISI 304 stainless monotubolar fixed bed reactor (diameter of $25.4 \mathrm{~mm}$ and a length of $300 \mathrm{~mm}$ ). It is filled with nickel (Ni) catalyst pellets.

Finally, the reaction products go to the water separation section, constituted by a $6 \mathrm{~mm}$ stainless steel cooling coil, immersed in a thermostatic bath. In this section, water vapor condensation occurs and the gaseous incondensable products are collected for gas chromatographic analysis. The gaseous mixture flow rate is $0.63 \mathrm{~m}^{3} \mathrm{~h}^{-1}$. The installation of the apparatus is shown in Fig. 4. Gas flows are measured and controlled by flowmeters, supplied by Bronkhorst (El-flow Series), with the following characteristics: flow rate in the range from 0.08 to $4 \mathrm{Nm}^{3} / \mathrm{h}$; maximum inlet pressure $3 \mathrm{MPa}$; control stability lower than $\pm 0.1 \% \mathrm{FS}$ and temperature sensitivity lower than $0.05 \% \mathrm{FS} / \mathrm{K}$.

The two cameras are provided with temperature and pressure sensors:

- bourdon tube pressure gauge (NG100 series) supplied by Kobold (accuracy class 1), with a pressure range from 0 to $4 \mathrm{MPa}$;

- mineral insulated type $\mathrm{K}$ thermocouples (accuracy class 1 ).

Voltage signals from pressure transducers and temperature sensors are collected by a software for data acquisition on a personal computer. Pressure and temperature data are collected every $5 \mathrm{~s}$. Gas chromatographic analyses are carried out with a gas chromatographer supplied by VARIAN (model VARIAN CP 4900 Micro-GC). Measurements, periodically carried out with certified mixtures, show that uncertainties are always lower than $1 \%$, with an excellent repeatability on sequences of samples [18].

The Sabatier reaction is catalyzed by Ni-based catalyst supplied by BASF (G1-85 T5x5). BASF G1-85 Ni/ $\mathrm{Zr} / \mathrm{Al}_{2} \mathrm{O}_{3}$ catalyst contains metallic nickel and zirconium on an aluminum oxide support: the nickel content in weight is $50 \%$. It is supplied in $1 \mathrm{~mm} \times 4 \mathrm{~mm}$ cylindrical pellets, with a specific surface area of $123 \mathrm{~m}^{2} \mathrm{~g}^{-1}$. The nickel oxide (NiO) is converted into the catalytically active form for the methanation reaction through an activation process described in [9]. Gas bottles were supplied by Air Liquide Italia Service. The purity of $\mathrm{CO}_{2}, \mathrm{~N}_{2}$ and $\mathrm{H}_{2}$ used in the $\mathrm{CO}_{2}$ methanation process for catalyst activation is $99.999 \%$.

Three tests were carried out continuously using a stoichiometric $\mathrm{H}_{2}$ / $\mathrm{CO}_{2}$ ratio equal to $4\left(\mathrm{H}_{2}\right.$ volume fraction and $\mathrm{CO}_{2}$ volume fraction equal to $80 \%$ and $20 \%$, respectively) and with an hourly space velocity (the ratio between the flowrate and the reactor volume) of $413 \mathrm{~h}^{-1}$. Experimental tests were carried out with an initial internal temperature near to $673 \mathrm{~K}$ and an initial internal pressure from $0.2 \mathrm{MPa}$ to $2 \mathrm{MPa}$. Table 3 shows temperature and pressure values (referred to the internal initial conditions and measured inside the reactor at the steady state), final volume fractions in the gaseous mixture and $\mathrm{CO}_{2}$ conversion efficiency. The reaction time, which is considered to start from the temperature increase, was equal to $30 \mathrm{~min}$ for all the tests.

The $\mathrm{CO}_{2}$ conversion increases with pressure. Test at 2.0 MPa and at

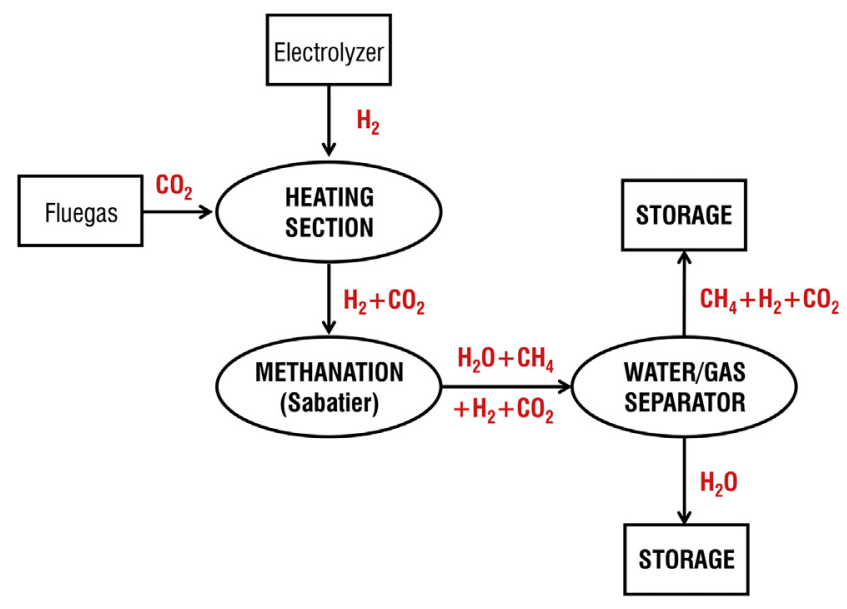

Fig. 3. Methanation process. 


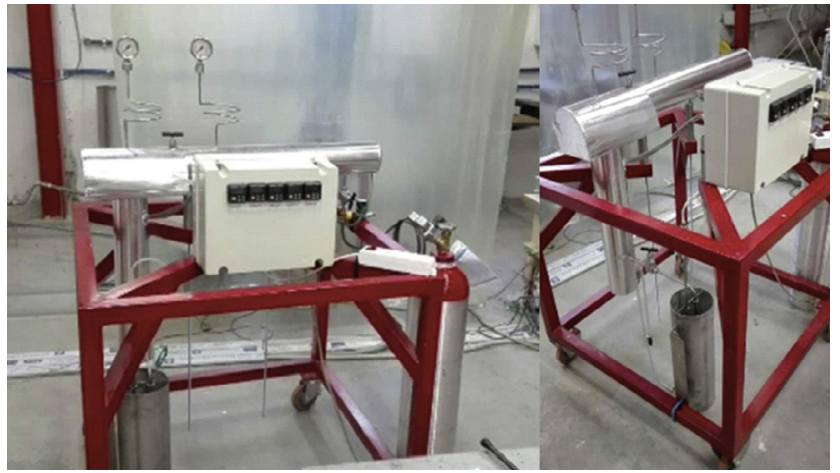

Fig. 4. Experimental apparatus for $\mathrm{CO}_{2}$ methanation process: (a) front view; (b) side view.

Table 3

Test conditions for $\mathrm{CO}_{2}$ methanation.

\begin{tabular}{|c|c|c|c|c|c|c|}
\hline \multirow[t]{2}{*}{ Test } & \multirow{2}{*}{$\begin{array}{l}\text { Pressure } \\
{[\mathrm{MPa}]}\end{array}$} & \multirow[t]{2}{*}{ Temperature $[\mathrm{K}]$} & \multicolumn{3}{|c|}{ Final $\% v / v$} & \multirow{2}{*}{$\begin{array}{l}\mathrm{CO}_{2} \text { conversion } \\
\text {-efficiency [\%] }\end{array}$} \\
\hline & & & $\mathrm{H}_{2}$ & $\mathrm{CH}_{4}$ & $\mathrm{CO}_{2}$ & \\
\hline 1 & 0.2 & 690 & 26.52 & 65.70 & 7.78 & 64.58 \\
\hline 2 & 1.0 & 675 & 24.58 & 64.75 & 3.95 & 80.25 \\
\hline 3 & 2.0 & 694 & 2.68 & 96.43 & 0.89 & 95.55 \\
\hline
\end{tabular}

an internal temperature of $694 \mathrm{~K}$, with a stoichiometric $\mathrm{CO}_{2} / \mathrm{H}_{2}$ ratio shows a $\mathrm{CO}_{2}$ conversion equal to $95.55 \%$.

\subsubsection{Ammonia production}

$\mathrm{NH}_{3}$ has a number of favorable attributes both as $\mathrm{H}_{2}$ carrier if compared to other $\mathrm{H}_{2}$ storage materials and as fuel. First of all, $\mathrm{NH}_{3}$ has a high capacity for $\mathrm{H}_{2}$ storage (about $17.7 \%$ stoichiometric content of $\mathrm{H}_{2}$ ) [14]. Furthermore, the $\mathrm{NH}_{3}$ production is based on a very wellknown process, and technologies and plants for a large scale $\mathrm{NH}_{3}$ production and distribution are already available [34]. Comparing $\mathrm{NH}_{3}$ with $\mathrm{H}_{2}$ and various other fuels, it can make sense to store $\mathrm{H}_{2}$ as $\mathrm{NH}_{3}$, characterized by an energy content equivalent to $21.23 \mathrm{MJ} \mathrm{kg}^{-1}$. Another important aspect of $\mathrm{NH}_{3}$ is that it contains no carbon. Therefore, when ammonia-based fuel is burned, it produces lower greenhouse gases emissions.

Technologies for ammonia storage are also well-developed. $\mathrm{NH}_{3}$ is a compound with relative stability, liquid at $288 \mathrm{~K}$ and with a vapor tension of $0.6 \mathrm{MPa}$. It liquefies at ambient temperatures at about $1.0 \mathrm{MPa}$ or at $240 \mathrm{~K}$ at $0.1 \mathrm{MPa}$; it is also stored as liquid solution with water. It has decreasing solubility in solvent liquids as the temperature of the solvent increases; at $288.6 \mathrm{~K}$, the density of a saturated solution is $880 \mathrm{~kg} \mathrm{~m}^{-3}$ and contains $35 \% \mathrm{NH}_{3}$ by mass. In general, three methods of storage of liquid $\mathrm{NH}_{3}$ are currently used: at ambient temperature and equivalent pressure, under pressure in spherical vessels, and at atmospheric pressure at $240 \mathrm{~K}$. The choice depends primarily on the quantity of liquid $\mathrm{NH}_{3}$ to store, the economic aspect and the end use. In this study, $\mathrm{NH}_{3}$ was considered compressed at about 1.0 MPa.

The Haber-Bosch reaction used for $\mathrm{NH}_{3}$ production from $\mathrm{N}_{2}$ and $\mathrm{H}_{2}$ is highly exothermic and produces $92 \mathrm{~kJ} \mathrm{~mol}^{-1}$. Optimal values of temperature and pressure are included respectively between 623 and $823 \mathrm{~K}$ and 14-32 MPa. High temperatures are necessary to split the binitrogen molecule, or to break triple bond existing between the two nitrogen atoms. In this way, kinetics of the separation reaction is accelerated but at the same time, this value of temperature makes the synthesis reaction more complicated. The most widely used catalyst is iron, because of its availability and its low cost.

Aluminum oxides are added to the catalytic mixture to protect the catalyst and to hinder this process. The industrial process is composed of several steps. $\mathrm{H}_{2}$ and $\mathrm{N}_{2}$ are compressed to reach the optimal value,

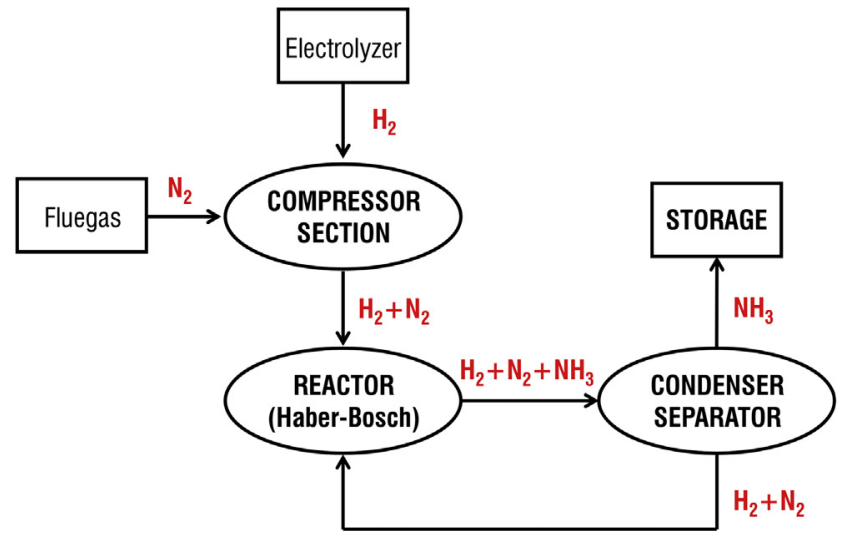

Fig. 5. Scheme of Haber-Bosch process.

and then they are sent to the reactor where the heater heats them to the right temperature and catalysts work for $\mathrm{NH}_{3}$ production. At the exit of the reactor, there is $\mathrm{NH}_{3}$, and also unreacted $\mathrm{H}_{2}$ and $\mathrm{N}_{2}$. This mixture goes to a heat exchange, which separates a part of unreacted reagents and sends them to the reactor. The other part of the mixture has a high $\mathrm{NH}_{3}$ percentage and reaches a capacitor in order to obtain pure $\mathrm{NH}_{3}$. The remaining part of reactants is compressed a second time and sent to the heat exchanger, then to the reactor. The produced $\mathrm{NH}_{3}$ is then stored. The process units are shown in Fig. 5. A recycling loop is generally used since single-stage reactant conversion is very low and equal to $15-20 \%$ [35]. Improved Haber-Bosch plant configurations have been proposed based on the integration with biogas or gasification plants [36].

Current industrial $\mathrm{NH}_{3}$ plants use $\mathrm{H}_{2}$ production processes, steam/ air reforming and partial oxidation process. The type of feedstock used plays a significant role in the consumed energy amount and in the produced $\mathrm{CO}_{2}$. The steam reforming of natural gas produces $2.1 \mathrm{~kg}_{\mathrm{CO} 2}$ $\mathrm{kg}_{\mathrm{NH} 3}^{-1}$, while in partial oxidation the emissions are in the range 3.3-4.6 $\mathrm{kg}_{\mathrm{CO} 2} \mathrm{~kg}_{\mathrm{NH} 3}^{-1}$ depending on the feedstock. According to literature studies, the average energy consumption in $93 \mathrm{NH}_{3}$ plants was $36.6 \mathrm{MJ} \mathrm{kg}_{\mathrm{NH} 3}^{-1}$ [37].

\subsection{Energy and environmental evaluation}

In the following subsections, the energy balance of the process and the method for energy and carbon footprint analysis are detailed.

\subsubsection{Energy balance}

Flue gas was assumed to be a gas mixture of $\mathrm{CO}_{2}$ and $\mathrm{N}_{2}(20 \%$ in volume of $\mathrm{CO}_{2}$ ) at $293 \mathrm{~K}$ and $0.1 \mathrm{MPa}$ [38]. $1 \mathrm{~kg}$ of flue gas is constituted by $25.6 \mathrm{~mol}$ of $\mathrm{N}_{2}$ and $6.4 \mathrm{~mol}$ of $\mathrm{CO}_{2}$. For $\mathrm{CO}_{2} / \mathrm{N}_{2}$ separation, a two-stage membrane separation process with a $\mathrm{CO}_{2}$ purity of $95 \%$ and a $\mathrm{CO}_{2}$ separation degree of $90 \%$ was considered. The specific energy consumption was calculated in [39] and is equal to $878.4 \mathrm{~kJ}_{\mathrm{el}} \mathrm{kg}_{\mathrm{CO} 2}^{-1}$. Considering the composition of the flue gas, the energy consumption is equal to $235 \mathrm{~kJ}_{\mathrm{el}} \mathrm{kg}_{\text {fluegas. }}^{-1}$. After separation, which is assumed to ensure $90 \% \mathrm{CO}_{2}$ separation and a $95 \mathrm{~mol} \% \mathrm{CO}_{2}$ purity, $6.1 \mathrm{~mol}$ of $\mathrm{CO}_{2}$ at $0.4 \mathrm{MPa}$ are used for the Sabatier reaction and $24.4 \mathrm{~mol}$ of $\mathrm{N}_{2}$ are used for the Haber-Bosch reaction. $\mathrm{H}_{2}$ is produced by electrolysis of water. The $\mathrm{H}_{2}$ moles necessary for Sabatier reaction and $\mathrm{NH}_{3}$ production are calculated using the stoichiometric proportions and are equal to 97.4 moles $_{\mathrm{H} 2} \mathrm{~kg}_{\text {fluegas. }}^{-1}$ Energy consumption for the electrolysis is equal to $13680 \mathrm{~kJ} \mathrm{Nm}_{\mathrm{H} 2}^{-3}$ as in [33]. Energy costs related to the methanation process consist of:

- $\mathrm{H}_{2}$ and $\mathrm{CO}_{2}$ compression for injection into the synthesis reactor,

- energy consumption for reactor's heating to the synthesis temperature, 


\section{- removal of reaction heat.}

To assess the above cited contributions, the following assumptions were made. $\mathrm{H}_{2}$ is compressed to $0.4 \mathrm{MPa}$ and then mixed with $\mathrm{CO}_{2}$ from the separation section. The gaseous mixture is compressed from $0.4 \mathrm{MPa}$ to $2.0 \mathrm{MPa}$, with an initial temperature of $293 \mathrm{~K}$, through a single stage compression. The following efficiencies were considered: isentropic efficiency equal to 0.85 , mechanical efficiency equal to 0.93 and electrical efficiency equal to 0.98 . The $\mathrm{H}_{2} / \mathrm{CO}_{2}$ mixture is heated to $724 \mathrm{~K}$ from the final compression temperature of $408 \mathrm{~K}$ in order to reach the operating conditions. Heating is assumed to be carried out by band heaters as in Section 2.1.3; the energy conversion efficiency is assumed equal to 0.75 to take into account heat losses. Sabatier reaction is an exothermic process, with an enthalpy of formation of $165 \mathrm{~kJ} \mathrm{~mol}^{-1}$. Reaction heat is considered to be removed through a cooling process with a coefficient of performance (COP) equal to 3 . Water-methane separation is not considered since it occurs at environmental temperature. For the $\mathrm{NH}_{3}$ production, $\mathrm{N}_{2}$ is mixed with $\mathrm{H}_{2}$ with 1:3 stoichiometric ratio. As for the methanation section, energy costs consist of $\mathrm{H}_{2}$ and $\mathrm{N}_{2}$ compression, heating to the synthesis temperature and removal of reaction heat and the same assumptions were considered for the calculation. The mixture is considered to be compressed to $25 \mathrm{MPa}$ with a four-stage compression with intercooling. The mixture is then heated to $823 \mathrm{~K}$. The reaction heat, equal to $45.64 \mathrm{~kJ} \mathrm{~mol}^{-1}$ is removed with a chiller with a COP equal to $3 . \mathrm{NH}_{3}$ separation is a condensation process, whose energy consumption is considered equal to zero. The analyzed energy costs are summarized in Table 4.

The total energy consumption per mass unit of flue gas is equal to $36,328 \mathrm{~kJ}_{\mathrm{el}}$, which corresponds to $186,418 \mathrm{~kJ}$ el per unit mass of $\mathrm{H}_{2}$. The electrolysis covers almost $80 \%$ of the electrical energy costs. The corresponding primary energy need, considering a conversion factor of 0.46 , is $78973 \mathrm{~kJ} \mathrm{~kg}_{\text {fluegas }}^{-1}$ equal to $405,256 \mathrm{~kJ}_{\mathrm{el}} \mathrm{kg}_{\mathrm{H} 2}^{-1}$. The electric energy/primary energy conversion factor is related to the Italian energy scenario and determined by the Italian authority ARERA [40].

The investigated process produces $5.8 \mathrm{~mol}(0.166 \mathrm{~kg})$ of $\mathrm{CH}_{4}$ and $9.7 \mathrm{~mol}\left(0.092 \mathrm{~kg}\right.$ ) of $\mathrm{NH}_{3}$ (Table 5 ). The conversion of a mass unit of $\mathrm{H}_{2}$ leads to $0.475 \mathrm{~kg}$ of $\mathrm{CH}_{4}$ and $0.850 \mathrm{~kg}$ of $\mathrm{NH}_{3}$. To calculate the energy output, the following considerations were made. For the Sabatier reaction, the experimental conversion efficiency, obtained in Section 2.3 and equal to $95 \%$, was considered. For the $\mathrm{NH}_{3}$ production, the conversion efficiency was assumed equal to $20 \%$, as found in the literature [41]. For both processes, calculations refer to a single-stage process without reactant recirculation. Since heat of combustion is equal to $50000 \mathrm{~kJ} \mathrm{~kg}^{-1}$ and $18480 \mathrm{~kJ} \mathrm{~kg}^{-1}$ for $\mathrm{CH}_{4}$ and $\mathrm{NH}_{3}$, respectively, the energy output for mass unit of flue gas is $7684 \mathrm{~kJ}$ (Table 5). The energy output for mass unit of $\mathrm{H}_{2}$ is $39433 \mathrm{~kJ}$.

\subsubsection{Carbon and energy footprint method}

The life-cycle CF and EF are performed with the SimaPro ${ }^{\circledR}$ v8.4.0.0 software [42] in accordance with ISO/TS 14,067 [43] and the ISO 14,040 series [44]. The standard CF method IPCC 2013 GWP 100a within the SimaPro software is used [42]; the quantification is based on the activity data multiplied by appropriate emission factors that quantify $\mathrm{CO}_{2 \text { eq }}$ emissions per unit activity. The GHG emissions associated to the $i$-th process $\left(C F_{i}\right)$ is computed using equation (4):

$C F_{i}=E F_{i} \cdot A_{i}$

where $A_{i}$ is the activity data and $E F_{i}$ is the emission factor of the $i$-th process, respectively.

The life-cycle primary energy consumption is also computed selecting the Cumulative Energy Demand (CED) assessment method. The CED of a product or system throughout the entire life cycle includes both the direct and indirect energy use, allowing the calculation of the EF. This enables the evaluation of the primary energy consumption and the GHG emissions associated to the flue gas treatment process for the production of $\mathrm{NH}_{3}$ via Haber-Bosch synthesis and the production of $\mathrm{CH}_{4}$ via Sabatier reaction starting from flue gas separation.

The LCA analysis was carried out in accordance with a cradle-togate approach, considering input material and production phases of a ready-to-use gas. The reference functional unit is $1 \mathrm{~kg}$ of flue gas treated in input, but results will be presented also for $1 \mathrm{~kg}$ of $\mathrm{H}_{2}$ used. The system boundaries,given in Fig. 6, are focused on all the processes and materials required to convert flue gas into $\mathrm{CH}_{4}$ and $\mathrm{NH}_{3}$. In particular, they include the production of input materials (i.e. reagents, water, catalyst, and membrane), and the production of energy required by separation, electrolysis, methanation and ammonia synthesis processes. The boundaries do not include the energy conversion of the $\mathrm{CH}_{4}$ and $\mathrm{NH}_{3}$ produced. A mass allocation was used to evaluate the impact, in terms of energy and GHG emissions, of the different phases of the process.

The energy needs for the process steps are supplied by a renewable multicrystalline PV system. The solar technology was determined on the basis of its CF. In accordance with Ecoinvent database within SimaPro Software [42], multicrystalline silicon solar cells have a CF of $20.5 \mathrm{~kg}_{\mathrm{CO} 2 \mathrm{eq}}$ per GJ produced, while single crystalline silicon solar cells have a CF of $24.2 \mathrm{~kg}_{\mathrm{CO} 2 \mathrm{eq}}$ per GJ produced. To study also the case in which the renewable electricity excess is not available, the LCA analysis was carried out also for the case of the electricity supply from the grid.

Inventory data referred to $1 \mathrm{~kg}$ of flue gas treated are shown in Table 6. For the evaluation of the amount of membrane and catalyst necessary for the treatment of $1 \mathrm{~kg}$ of flue gas, the lifetime and the annual working hours were considered.

To quantify the membrane needed to treat $1 \mathrm{~kg}$ of flue gas, a lifetime of 10 years, a total weight of $0.475 \mathrm{~kg}, 700 \mathrm{~h} \mathrm{y}^{-1}$, and a flow rate 3.6 $\mathrm{Sm}^{3} \mathrm{~h}^{-1}$ are considered.

In Table 6 process energy needs are covered by electricity. Electricity is used for reactants' compression and heating and for removal of reaction heat. For $\mathrm{CO}_{2}$ methanation, inventory data are based on the configuration and operation of the experimental apparatus in which heat is supplied by electrical band heaters. In industrial plants, heat recovery allows to obtain much more efficient configurations: the heat of the methanation reaction, for instance, could be used for the regeneration of scrubbing liquids or sorbents in the $\mathrm{CO}_{2}$ separation section or, alternatively, for pre-heating reactants.

Electricity input in ammonia industrial plants is not used, as most of $\mathrm{NH}_{3}$ production is based on steam reforming in which heat recovered from the primary reformer flue gas is used to produce high pressure steam used to drive synthesis gas, process air and refrigeration compressors [45]. In addition, gases from reforming sections, before entering the synthesis reactor, are already at high temperature. Heat needs are generally supplied by burning natural gas or other gaseous fuel. This configuration is not consistent with the presented process, in which steam reforming is replaced by water electrolysis.

Table 4

Energy input for $\mathrm{CO}_{2}$ methanation and $\mathrm{NH}_{3}$ production.

\begin{tabular}{llll}
\hline Energy input & & & \\
Process & Energy consumption & $\left(\mathrm{kJ}_{\mathrm{el}} \mathrm{kg}_{\text {fluegas }}^{-1}\right)$ & $\left(\mathrm{kJ}_{\mathrm{el}} \mathrm{kg}_{\mathrm{H} 2}^{-1}\right)$ \\
\hline $\mathrm{N}_{2} / \mathrm{CO}_{2}$ separation & Membrane separation & 235 & 1208 \\
$\mathrm{H}_{2}$ production & Electrolysis & 29,839 & 153,120 \\
$\mathrm{CO}_{2}$ methanation & Compression & 1498 & 7686 \\
& Gas mixture heating & 1354 & 6947 \\
$\mathrm{NH}_{3}$ synthesis & Reaction heat removal & 318 & 1631 \\
& 4-stage compression & 1625 & 8341 \\
& Gas mixture heating & 1384 & 7104 \\
Total energy consumption & 74 & 380 \\
& Reaction heat removal & 36,328 & 186,418
\end{tabular}


Table 5

Energy output for $\mathrm{CO}_{2}$ methanation and $\mathrm{NH}_{3}$ production.

\begin{tabular}{llllll}
\hline \multicolumn{3}{c}{ Energy output } & & \\
\cline { 2 - 5 } Product & $\begin{array}{l}\text { Amount } \\
(\mathrm{mol} \\
\left.\mathrm{kg}_{\text {fluegas }}^{-1}\right)\end{array}$ & $\begin{array}{l}\text { Amount }(\mathrm{kg} \\
\mathrm{kg}_{\text {fluegas }}^{-1}\end{array}$ & $\begin{array}{l}\text { Amount } \\
\left(\mathrm{kg} \mathrm{kg}_{\mathrm{H} 2}^{-1}\right)\end{array}$ & $\begin{array}{l}\text { Energy } \\
\text { content }(\mathrm{kJ} \\
\mathrm{kg}_{\text {fluegas }}^{-1}\end{array}$ & $\begin{array}{l}\text { Energy } \\
\text { content kJ } \\
\left.\mathrm{kg}_{\mathrm{H} 2}^{-1}\right)\end{array}$ \\
\hline $\mathrm{CH}_{4}$ & 5.8 & 0.092 & 0.475 & 4623 & 23,725 \\
$\mathrm{NH}_{3}$ & 9.7 & 0.166 & 0.850 & 3061 & 15,708 \\
\hline
\end{tabular}

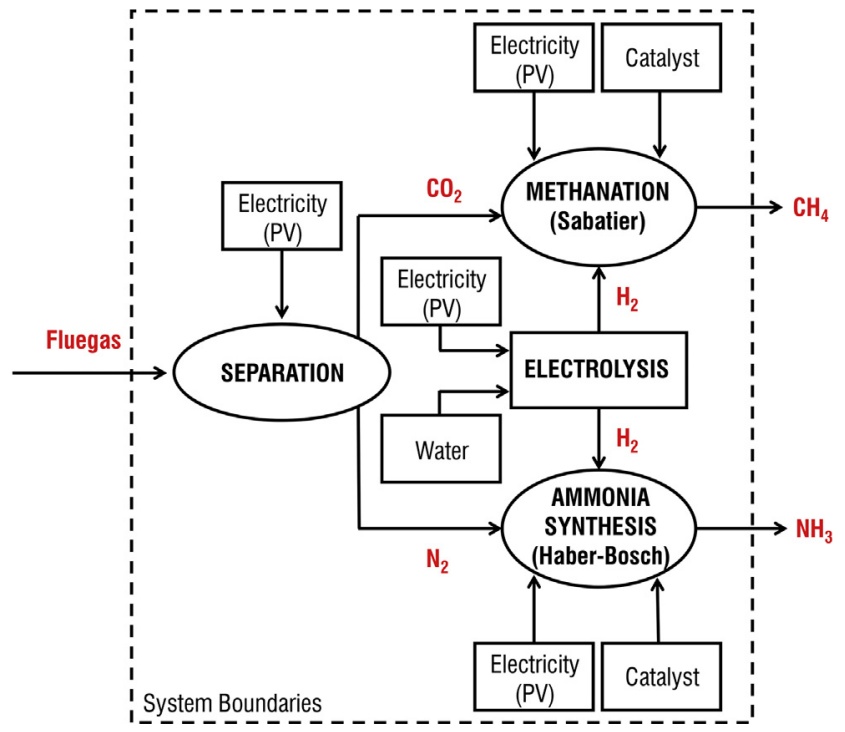

Fig. 6. System boundaries.

Table 6

Inventory data for the treatment of $1 \mathrm{~kg}$ of flue gas.

\begin{tabular}{lllll}
\hline Phase & Input & Unit & Amount & Data source \\
\hline \multirow{2}{*}{ Flue gas separation } & Membrane & $\mathrm{kg}$ & $1.03 \mathrm{E}-05$ & Computational data \\
& Electricity & $\mathrm{kJ}$ & 235 & Computational data \\
$\mathrm{CO}_{2}$ methanation & $\mathrm{H}_{2}$ & $\mathrm{~kg}$ & 0.04871 & Experimental data \\
& Electricity & $\mathrm{kJ}$ & 3169 & Experimental data \\
& Catalyst & $\mathrm{kg}$ & $7.69 \mathrm{E}-05$ & Experimental data \\
$\mathrm{NH}_{3}$ synthesis & $\mathrm{H}_{2}$ & $\mathrm{~kg}$ & 0.1461 & Computational data \\
& Electricity & $\mathrm{kJ}$ & 3084 & Computational data \\
& Catalyst & $\mathrm{kg}$ & $1.04 \mathrm{E}-05$ & Computational data \\
\hline
\end{tabular}

\section{Results and discussion}

Results of the LCA analysis show that, considering $1 \mathrm{~kg}$ of flue gas as functional unit of the study, CF and EF are $0.7819 \mathrm{~kg}_{\mathrm{CO} 2 \mathrm{eq}} \mathrm{kg}^{-1}$ and $50.73 \mathrm{MJ} \mathrm{kg}^{-1}$, respectively. The process is formed by two sections: $\mathrm{CO}_{2}$ methanation and $\mathrm{NH}_{3}$ synthesis via Haber-Bosch reaction. The obtained results were calculated on the basis of experimental data for the methanation process and on numerical calculations for the $\mathrm{NH}_{3}$ section, in which a conversion efficiency of 0.2 without recirculation was considered. The estimate of the process footprint is performed considering that the electric energy, consumed within the process, is produced by PV. Fig. 7 shows the network view referred to the process that used electricity excess from renewable energy (in this case from PV).

A detail of $\mathrm{CF}$ analyses, when the required electricity is supplied by PV system, is given in Table 7. It can be noted that most of the environmental impact (approx. 99.8\%), in terms of GHG emissions, comes from energy consumption (Fig. 7). In particular, $\mathrm{H}_{2}$ electrolysis is responsible for $82 \%$ of the energy consumption.
From data in Table 7, the $\mathrm{CO}_{2}$ methanation process is responsible for $29.48 \%$ of $\mathrm{CF}\left(0.2305 \mathrm{~kg}_{\mathrm{CO} 2 \mathrm{eq}} \mathrm{kg}_{\text {fluegas }}^{-1}\right)$ and $29.45 \%$ of $\mathrm{EF}$ (14.94 $\mathrm{MJ} \mathrm{kg}_{\text {fluegas }}^{-1}$ ), respectively. The produced $\mathrm{CH}_{4}$ is equal to $0.092 \mathrm{~kg}$ (Table 5), corresponding to $0.129 \mathrm{Nm}^{3}$. For the $\mathrm{CO}_{2}$ methanation process, the $\mathrm{CF}$ and $\mathrm{EF}$ associated to the electricity from the solar renewable source are $8.71 \%$ and $8.72 \%$, respectively. From values in Tables 5 and 7 , the emitted $\mathrm{CO}_{2}$ per GJ of energy from the combustion of the produced $\mathrm{CH}_{4}$ is equal to $49.7 \mathrm{~kg}_{\mathrm{CO} 2 \mathrm{eq}} \mathrm{GJ}^{-1}$, which is much lower than that calculated in [5] $\left(112.7-118.9 \mathrm{~kg}_{\mathrm{CO} 2 \mathrm{eq}} \mathrm{GJ}^{-1}\right)$. This range is referred to a $\mathrm{CO}_{2}$ methanation process with different electrolyzer sizes from $25 \mathrm{~kW}$ to $1000 \mathrm{MW}$ and with $\mathrm{CO}_{2}$ supply from direct atmosphere capture.

The $\mathrm{NH}_{3}$ synthesis process is responsible for $70.52 \%$ of CF $(0.5514$ $\left.\mathrm{kg}_{\mathrm{CO} 2 \mathrm{eq}} \mathrm{kg}_{\text {fluegas }}^{-1}\right)$ and $70.55 \%$ of $\mathrm{EF}\left(35.79 \mathrm{MJ} \mathrm{kg}_{\text {fluegas }}^{-1}\right)$. The produced $\mathrm{NH}_{3}$ is equal to $0.166 \mathrm{~kg} \mathrm{~kg}_{\text {fluegas. }}^{-1}$ This value is very low because of the conversion efficiency assumed to be 0.2 . In real processes, with the presence of recirculation of unreacted $\mathrm{N}_{2} / \mathrm{H}_{2}$, the conversion efficiency reaches value up to 0.9 . Considering that the PV electricity consumption for the $\mathrm{NH}_{3}$ process has a very low impact on the overall $\mathrm{CF}$ and $\mathrm{EF}$ ( $8.47 \%$ and $8.49 \%$ respectively), an advanced production process with recirculation could be performed in order to reach higher $\mathrm{NH}_{3}$ production. In this case, the amount of produced $\mathrm{NH}_{3}$ would be $0.745 \mathrm{~kg} \mathrm{~kg}_{\text {fluegas }}^{-1}$ and $\mathrm{CF}$ would be $0.740 \mathrm{~kg}_{\mathrm{CO} 2 \mathrm{eq}} \mathrm{kg}_{\mathrm{NH} 3}^{-1}$. The $\mathrm{CF}$ of the process is much lower than data for $\mathrm{NH}_{3}$ production via traditional process, which show a $\mathrm{CF}$ in the range from 2.1 to $4.6 \mathrm{~kg}_{\mathrm{CO} 2 \mathrm{eq}} \mathrm{kg}_{\mathrm{NH} 3}^{-1}$, as reported in Section 2.1.4.

Comparing data of the methanation and the $\mathrm{NH}_{3}$ production processes, in both cases the weight of the PV electricity for process stages on the overall $\mathrm{CF}$ and $\mathrm{EF}$ is much lower than the consumed electric energy for $\mathrm{H}_{2}$ electrolysis, which results as the most energy-consuming section of the process. Despite this, producing $\mathrm{H}_{2}$ through the use of renewable solar energy becomes an important technological path for renewable energy storage, which helps in reducing fluctuation in electricity production and increasing grid production-demand balance in temporal and spatial dimensions.

To include also the case in which the renewable electricity excess is not available, a further analysis was computed for a system using the electricity from the grid, considering the production mix for Italy. Results are summarized in Table 8.

In case of energy supply from the grid, the $\mathrm{CF}$ is $1.550 \mathrm{~kg}_{\mathrm{CO} 2}$ and the $\mathrm{EF}$ is $59.12 \mathrm{MJ}$ per $\mathrm{kg}$ of flue gas, which correspond to $7.954 \mathrm{~kg}_{\mathrm{CO} 2}$ and 303.4 MJ per $\mathrm{kg}$ of $\mathrm{H}_{2}$ produced. Using the electricity from the grid leads to a double value of $\mathrm{CO}_{2}$ emissions with respect to the case of completely renewable energy use. The specific EF changes from $50.73 \mathrm{MJ}$ to $59.12 \mathrm{MJ}$, with a $14 \%$ increase.

In the face of a positive $\mathrm{CF}$, the integrated production of synthetic $\mathrm{CH}_{4}$ and $\mathrm{NH}_{3}$ from flue gas indirectly leads to avoided emissions, which should be accounted. Firstly, flue gas is not released in the atmosphere but converted into valuable products. The $\mathrm{CO}_{2}$ in a flue gas mass unit, not emitted into the atmosphere, is equal to $0.282 \mathrm{~mol}$.

The synthetized $\mathrm{CH}_{4}$ replaces that produced from fossil sources, while the produced $\mathrm{NH}_{3}$ replaces that produced from traditional processes. In accordance with literature data and Ecoinvent 3.3 database within SimaPro $^{\circledast}$ v8.4.0.0 Software [42], natural gas production at extraction has a $\mathrm{CF}$ equal to $0.0 .444 \mathrm{~kg}_{\mathrm{CO} 2 \mathrm{eq}} \mathrm{Nm}^{-3}$, while $\mathrm{NH}_{3}$ production emissions ranges from $1.99 \mathrm{~kg}_{\mathrm{CO} 2 \mathrm{eq}} \mathrm{kg}_{\mathrm{NH} 3}^{-1}$ for a steam reforming process to $3.02 \mathrm{~kg}_{\mathrm{CO} 2 \mathrm{eq}} \mathrm{kg}_{\mathrm{NH} 3}^{-1}$ for a partial oxidation process. In addition, the avoided carbon emissions related to $\mathrm{CH}_{4}$ production $(0.092 \mathrm{~kg})$ are equal to $0.061 \mathrm{~kg}_{\mathrm{CO} 2 \mathrm{eq}} \mathrm{kg}_{\text {fluegas }}^{-1}$ and those related to the $\mathrm{NH}_{3}$ production $(0.166 \mathrm{~kg})$ range from 0.330 to $0.501 \mathrm{~kg}_{\mathrm{CO} 2 \mathrm{eq}} \mathrm{kg}_{\text {fluegas}}^{-1}$, with an average value of $0.415 \mathrm{~kg}_{\mathrm{CO} 2 \mathrm{eq}} \mathrm{kg}_{\text {fluegas. }}^{-1}$. The total amount of the avoided $\mathrm{CO}_{2}$ emissions ranges from 0.673 to $0.844 \mathrm{~kg}_{\mathrm{CO} 2 \mathrm{eq}} \mathrm{kg}_{\text {fluegas }}^{-1}$ with an average value of $0.758 \mathrm{~kg}_{\mathrm{CO} 2 \mathrm{eq}} \mathrm{kg}_{\text {fluegas }}^{-1}$.

It can be stated that, in case of renewable energy excess use, the flue gas treatment path globally constitutes a carbon-neutral process, and even results in estimated negative balance values, thus proving the 


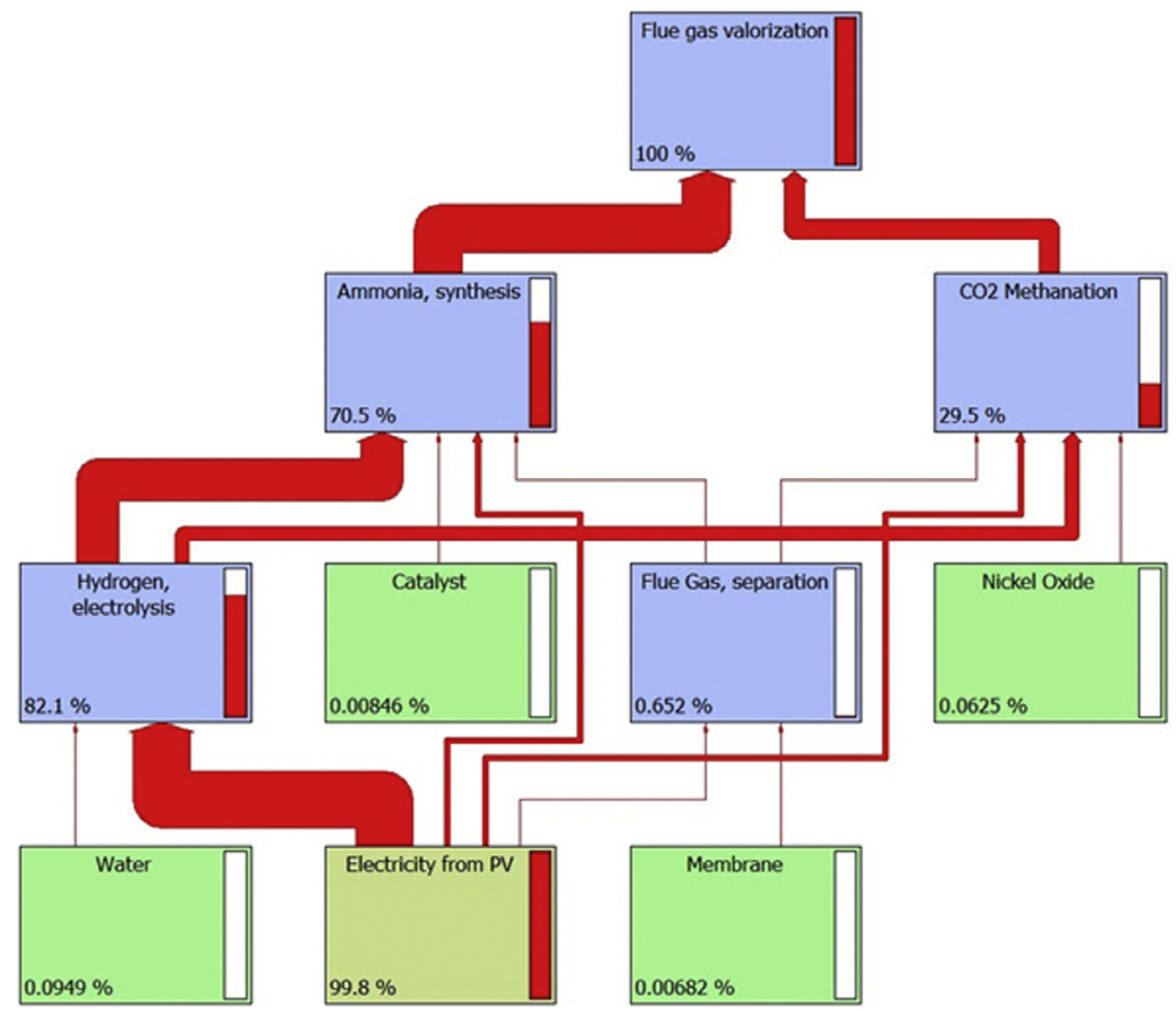

Fig. 7. Network view of CF results.

sustainability of the proposed process and its possible classification as a carbon recycling strategy to close the loop of $\mathrm{CO}_{2}$ and, at the same time, put back carbon neutral fuel into the system.

\section{Conclusions}

In this paper, the authors propose a novel path to treat flue gas, in which $\mathrm{H}_{2}$ production from electrolysis is integrated with ammonia production from $\mathrm{N}_{2}$ by Haber-Bosch process and $\mathrm{CH}_{4}$ production from $\mathrm{CO}_{2}$ by Sabatier reaction.

PtG when combined with $\mathrm{CO}_{2}$ and $\mathrm{N}_{2}$ capture and storage technologies can be seen as a double solution: to provide energy supply and, at the same time, to put back into the industrial cycle further raw
Table 8

Carbon and Energy Footprint considering Italian Energy mix.

\begin{tabular}{|c|c|c|c|c|}
\hline \multirow[t]{2}{*}{ Phase } & \multicolumn{2}{|c|}{ Carbon footprint } & \multicolumn{2}{|c|}{ Energy footprint } \\
\hline & $\begin{array}{l}\left(\mathrm{kg}_{\mathrm{CO} 2 \mathrm{eq}}\right. \\
\left.\mathrm{kg}_{\text {fluegas }}^{-1}\right)\end{array}$ & $\begin{array}{l}\left(\mathrm{kg}_{\mathrm{CO} 2 \mathrm{eq}}\right. \\
\left.\mathrm{kg}_{\mathrm{H} 2}^{-1}\right)\end{array}$ & (MJ kg fluegas) & $\left(\mathrm{MJ} \mathrm{kg}_{\mathrm{H} 2}^{-1}\right)$ \\
\hline $\mathrm{NH}_{3}$ synthesis & 0.9302 & 4.773 & 39.93 & 204.9 \\
\hline $\mathrm{CO}_{2}$ Methanation & 0.6197 & 3.180 & 19.19 & 98.48 \\
\hline Flue gas treatment & 1.550 & 7.954 & 59.12 & 303.4 \\
\hline
\end{tabular}

Table 7

Carbon and energy footprint.

\begin{tabular}{|c|c|c|c|c|c|c|}
\hline \multirow[t]{2}{*}{ Phase } & \multicolumn{3}{|l|}{ Carbon footprint } & \multicolumn{3}{|c|}{ Energy footprint } \\
\hline & $\left(\mathrm{kg}_{\mathrm{CO} 2 \mathrm{eq}} \mathrm{kg}_{\text {flueGas }}^{-1}\right)$ & $\left(\mathrm{kg}_{\mathrm{CO} 2 \mathrm{eq}} \mathrm{kg}_{\mathrm{H} 2}^{-1}\right)$ & (\%) & (MJ kgflueGas) & $(\mathrm{MJ} \mathrm{kg}-1)$ & $(\%)$ \\
\hline $\mathrm{CO}_{2}$ Methanation & 0.2305 & 1.183 & 29.48 & 14.94 & 76.65 & 29.45 \\
\hline Catalyst & 0.0004890 & 0.002509 & 0.06 & 0.006698 & 0.03437 & 0.01 \\
\hline Flue gas separation & 0.001439 & 0.007384 & 0.18 & 0.09280 & 0.4762 & 0.18 \\
\hline Electricity PV & 0.0681 & 0.3494 & 8.71 & 4.4230 & 22.70 & 8.72 \\
\hline $\mathrm{H}_{2}$, electrolysis & 0.1605 & 0.8235 & 20.52 & 10.42 & 53.45 & 20.53 \\
\hline $\mathrm{NH}_{3}$ Synthesis & 0.5514 & 2.830 & 70.52 & 35.79 & 183.6 & 70.55 \\
\hline Catalyst & $6.612 \mathrm{E}-05$ & $3.393 E-04$ & 0.01 & $9.058 \mathrm{E}-04$ & 0.004648 & 0.00 \\
\hline Flue gas separation & 0.003663 & 0.01880 & 0.47 & 0.2362 & 1.212 & 0.47 \\
\hline Electricity PV & 0.06626 & 0.3400 & 8.47 & 4.304 & 22.09 & 8.49 \\
\hline $\mathrm{H}_{2}$, electrolysis & 0.4814 & 2.5 & 61.57 & 31.25 & 160.3 & 61.60 \\
\hline Flue gas treatment & 0.7819 & 4.012 & 100 & 50.73 & 260.3 & 100 \\
\hline
\end{tabular}


materials flow for other kind of production purposes.

The process is studied through a LCA approach to determine carbon and energy footprint. Laboratory tests were performed to provide real data for $\mathrm{CF}$ and $\mathrm{EF}$ calculations. The reference functional unit is $1 \mathrm{~kg}$ of flue gas treated in input. The system boundaries include all the phases from production of input materials (reagents and water) and energy wares (electricity and $\mathrm{H}_{2}$ ). The main results of the study are summarized hereunder:

- Results of experimental tests on $\mathrm{CO}_{2}$ methanation section show a $\mathrm{CO}_{2}$ conversion equal to $95.55 \%$ at $2.0 \mathrm{MPa}$.

- The total energy consumption per mass unit of flue gas is equal to $36,328 \mathrm{~kJ}_{\mathrm{el}}$ and $186,418 \mathrm{~kJ}_{\mathrm{el}}$ per mass unit of $\mathrm{H}_{2}$. The electrolysis covers almost $80 \%$ of the electrical energy costs.

- From $1 \mathrm{~kg}$ of flue gas, $0.166 \mathrm{~kg}$ of $\mathrm{CH}_{4}$ and $0.092 \mathrm{~kg}$ of $\mathrm{NH}_{3}$ are produced.

- The total $\mathrm{CF}$ of the flue gas treatment process is $0.7819 \mathrm{~kg}_{\mathrm{CO} 2 \mathrm{eq}}$ $\mathrm{kg}_{\text {fluegas}}^{-1}$, in case of electricity excess from renewable energy $\mathrm{NH}_{3}$ production is responsible of about $70 \%$ of the carbon footprint while $\mathrm{CH}_{4}$ production is responsible of about $30 \%$.

- The analysis was computed also in case of electricity from the grid, when the renewable electricity excess is not available. In this case, the total $\mathrm{CF}$ of the flue gas treatment process is $1.550 \mathrm{~kg}_{\mathrm{CO} 2 \mathrm{eq}}$ $\mathrm{kg}_{\text {fluegas. }}^{-1}$

- In the face of a positive carbon footprint, the integrated production of synthetic $\mathrm{CH}_{4}$ and $\mathrm{NH}_{3}$ from flue gas indirectly leads to avoided emissions. The total amount of the avoided $\mathrm{CO}_{2}$ emissions ranges from 0.673 to $0.844 \mathrm{~kg}_{\mathrm{CO} 2 \mathrm{eq}} \mathrm{kg}_{\text {fluegas }}^{-1}$ with an average value of 0.758 $\mathrm{kg}_{\text {CO2eq }} \mathrm{kg}_{\text {fluegas. }}^{-1}$. This entails this process can be recommended to achieve carbon reduction targets by means of a $\mathrm{CO}_{2}$ recycling strategy.

\section{Acknowledgement}

The authors would like to acknowledge the Italian Ministry of Scientific Research and University for financially supporting the BIT3G project (code CTN01_00063_49295).

\section{References}

[1] European Parliament, Report on the implementation of the Circular Economy Plan, 2015. Available at < http://ec.europa.eu/environment/circular-economy/index _ en.htm > (Accessed on May 16, 2018).

[2] Suda T, Fujii M, Yoshida K, Iijima M, Seto T, Mitsuoka S. Development of flue gas carbon dioxide recovery technology. Energy Convers Manage 1992;33:317-24.

[3] Bailera M, Lisbona P, Romeo LM, Espatolero S. Power to Gas projects review: Lab, pilot and demo plants for storing renewable energy and $\mathrm{CO}_{2}$. Renew Sustain Energy Rev 2017;69:292-312.

[4] Collet P, Flottes E, Favre A, Raynal L, Pierre H, Capela S, et al. Techno-economic and Life Cycle Assessment of methane production via biogas upgrading and power to gas technology. Appl Energy 2017;192:282-95.

[5] Parra D, Zhang X, Bauer C, Patel MK. An integrated techno-economic and life cycle environmental assessment of power-to-gas systems. Appl Energy 2017;193:440-54.

[6] Castellani B, Morini E, Bonamente E, Rossi F. Experimental investigation and energy considerations on hydrate-based biogas upgrading with $\mathrm{CO}_{2}$ valorization. Biomass Bioenergy 2017;105:364-72.

[7] Zhang X, Bauer C, Mutel CL, Volkart K. Life cycle assessment of power-to-gas: ap proaches, system variations and their environmental implications. Appl Energy 2017; 190:326-38.

[8] Galindo Cifre P, Badr O. Renewable hydrogen utilisation for the production of methanol. Energy Convers Manage 2007;48:519-27.

[9] Castellani B, Gambelli AM, Morini E, Nastasi B, Presciutti A, Filipponi M, et al. Experimental investigation on $\mathrm{CO}_{2}$ methanation process for solar energy storage compared to $\mathrm{CO}_{2}$-based methanol synthesis. Energies 2017;10:855.

[10] Yoshida T, Tsuji M, Tamaura Y, Hurue T, Hayashida T, Ogawa K. Carbon recycling system through methanation of $\mathrm{CO}_{2}$ in flue gas in LNG power plant. Energy Convers Manage 1997;38:S443-8.

[11] Robinius M, Otto A, Heuser P, Welder L, Syranidis K, Ryberg DS, et al. Linking the power and transport sectors-Part 1: the principle of sector coupling. Energies 2017;10:956. http://dx.doi.org/10.3390/en10070956.

[12] Uusitalo V, Väisänen S, Inkeri E, Soukka R. Potential for greenhouse gas emission reductions using surplus electricity in hydrogen, methane and methanol production via electrolysis. Energy Convers Manage 2017;134:125-34.

[13] Gilbert P, Thornley P. Energy and carbon balance of ammonia production from biomass gasification, Bio-ten., Holiday Inn, Birmingham, September 21-23; 2010. On line at: < https://www.escholar.manchester.ac.uk/api/datastream? publicationPid = uk-acman-scw:91274\&datastreamId = FULL-TEXT.PDF $>$.

[14] Bicer Y, Dincer I, Zamfirescu C, Vezina G, Raso F. Comparative life cycle assessment of various ammonia production methods. J Cleaner Prod 2016;135:1379-95.

[15] Castellani B, Rinaldi S, Bonamente E, Nicolini A, Rossi F, Cotana F. Carbon and energy footprint of the hydrate-based biogas upgrading process integrated with $\mathrm{CO}_{2}$ valorization. Sci Total Environ 2018;615:404-11.

[16] Xu X, Song C, Wincek R, Andresen JM, Miller BG, Scaroni AW. Separation of $\mathrm{CO}_{2}$ from power plant flue gas using a novel $\mathrm{CO}_{2}$ "Molecular Basket" adsorbent. Fuel Chem Div Preprints 2003;48:162.

[17] Holladay JD, Hu J, King DL, Wang Y. An overview of hydrogen production tech nologies. Catal Today 2009;139:244-60.

[18] Castellani B, Rossi F, Filipponi M, Nicolini A. Hydrate-based removal of carbon dioxide and hydrogen sulphide from biogas mixtures: experimental investigation and energy evaluations. Biomass Bioenergy 2014;70:330-8.

[19] Aaron D, Tsouris C. Separation of $\mathrm{CO}_{2}$ from flue gas: a review. Sep Sci Technol 2005; 40:321-48.

[20] Ahmad F, Lau KK, Lock SSM, Rafiq S, Khan AU, Lee M. Hollow fiber membrane model for gas separation: process simulation, experimental validation and module characteristics study. J Ind Eng Chem 2015;21:1246-57.

[21] Songolzadeh M, Soleimani M, Ravanchi MT, Songolzadeh R. Carbon dioxide separation from flue gases: a technological review emphasizing reduction in greenhouse gas emissions. Sci World J 2014, Article ID 828131, 34 pages, 2014. https:// doi.org/10.1155/2014/828131.

[22] Powell CE, Qiao GG. Polymeric $\mathrm{CO}_{2} / \mathrm{N}_{2}$ gas separation membranes for the capture of carbon dioxide from power plant flue gases. J Membr Sci 2006;279:1-49.

[23] Moghadassi A, Marjani A, Shirazian S, Moradi S. Gas separation properties of hollow-fiber membranes of polypropylene and polycarbonate by melt-spinning method. Asian J Chem 2011;23:1922-4.

[24] Robb WL. Thin silicone membranes-their permeation properties and some applications. Ann N Y Acad Sci 1968;146:119-37.

[25] Membrane Basics. Available online at: < https://www.permselect.com/ membranes $>$ (Accessed on November 27, 2017).

[26] Van Der Sluijs JP, Hendriks CA, Blok K. Feasibility of polymer membranes for carbon dioxide recovery from flue gases. Energy Convers Manage 1992;33:429-36.

[27] Zhao L, Riensche E, Menzer R, Blum L, Stolten D. A parametric study of $\mathrm{CO}_{2} / \mathrm{N}_{2}$ gas separation membrane processes for post-combustion capture. J Membr Sci 2008;325:284-94.

[28] Zhao L, Riensche E, Blum L, Stolten D. How gas separation membrane competes with chemical absorption in postcombustion capture. Energy Procedia 2011;4:629-36.

[29] Saba SM, Müller M, Robinius M, Stolten D. The investment costs of electrolysis - a comparison of cost studies from the past 30 years. Int J Hydrogen Energy, Available online 11 December 2017, ISSN 0360-3199.

[30] Schmidt O, Gambhir A, Staffell I, Hawkes A, Nelson J, Few S. Future cost and performance of water electrolysis: an expert elicitation study. Int J Hydrogen Energy 2017:42:30470-92.

[31] Schiebahn S, Grube T, Robinius M, Tietze V, Kumar B, Stolten D. Power to gas: Technological overview, systems analysis and economic assessment for a case study in Germany. Int J Hydrogen Energy 2015;40:4285-94.

[32] Maslovara SL, Miulovic SM, Kaninski MPM, Tasic GS, Nikolic VM. Energy consumption of the electrolytic hydrogen production using Zn-Co-Mo based activators-Part I. Appl Catal A 2013;451:216-9.

[33] Nel Hydrogen; 2017. Available at < http://nelhydrogen.com/product/ electrolysers/ $>$ (Accessed on November 12)

[34] Di Profio P, Arca S, Rossi F, Filipponi M. Comparison of hydrogen hydrates with existing hydrogen storage technologies: energetic and economic evaluations. Int $\mathrm{J}$ Hydrogen Energy 2009;34:9173-80.

[35] Appl M. Process steps of ammonia production, in ammonia: Principles and industrial practice. Weinheim, Germany: Wiley-VCH Verlag GmbH; 1999.

[36] Frattini D, Cinti G, Bidini G, Desideri U, Cioffi R, Jannelli E. A system approach in energy evaluation of different renewable energies sources integration in ammonia production plants. Renew Energy 2016;99:472-82.

[37] International Fertilizer Industry Association (IFA). Energy Efficiency and CO2 Emissions in Ammonia Production 2008-2009 Summary Report Available at http:// www.inference.org.uk/sustainable/images/2009_tech_energy_efficiency.pdf [Accessed on November 12, 2017]

[38] Filipponi M, Rossi F, Rossi R. Use of molten carbonate fuel cell for $\mathrm{CO}_{2}$ capture. ECS Trans 2012;42(1):43-7.

[39] Zhang Y, Ji X, Lu X. Energy consumption analysis for $\mathrm{CO}_{2}$ separation from gas mixtures. Appl Energy 2014;130:237-43.

[40] Autorità di regolazione per Energia Reti e Ambiente. Delibera EEN 3/08. Available online at: < https://www.arera.it/it/docs/08/003-08een.htm\# > [Accessed on 22 January 2018].

[41] Zhao L, Riensche E, Weber M, Stolten D. Cascaded membrane processes for postcombustion $\mathrm{CO}_{2}$ capture. Chem. Eng. Technol 2012;35:489-96.

[42] SimaPro Software. Available at $<$ https://support.simapro.com/?c $=$ Getting Started\%3AGS All > [Accessed on 11 December 2017].

[43] ISO (International Standard Organization). ISO/TS 14067:2013 Greenhouse gases-carbon footprint of products-requirements and guidelines for quantification and communication. Geneva, Switzerland: International Organization for Standardization (ISO); 2013.

[44] ISO (International Standard Organization). ISO 14044:2006a environmental management-life cycle assessment-requirements and guidelines. Geneva, Switzerland: International Organization for Standardization (ISO); 2006.

[45] Ruddock J, Short TD, Brudenell K. Energy integration in ammonia production. Transactions on Ecology and the Environment 2003 vol 62, WIT Press, ISSN 17433541 . 